\title{
PENGARUH MEREK, DESAIN PRODUK DAN LOKASI TERHADAP MINAT BELI KONSUMEN PADA PERSEBAYA STORE GRESIK
}

\author{
Aris Susanto \\ Progran Studi Manajemen, Fakultas Ekonomi dan Bisnis, Universitas Muhammadiyah Gresik \\ arissusanto@gmail.com
}

\begin{abstract}
The purpose of this study was to determine the effect of brand, product design and location on consumer buying interest in Persebaya Store Gresik. The sample uses a non probability sampling method with a purposive sampling or random sampling procedure by selecting 100 visitors. The data analysis technique uses multiple linear regression. The results of multiple linear regression analysis prove that the brand and location proved not to have a significant effect partially on consumer buying interest in Persebaya Store Gresik, while product design proved to have a partially significant influence on consumers' buying interest in consumer buying interests at Persebaya Store Gresik. Simultaneously the brand, product design and location proved to have a significant effect on consumers' buying interest in Persebaya Store Gresik.
\end{abstract}

\section{Keywords: Brand, Product Design, Location and Buying Interest}

\section{PENDAHULUAN}

Perkembangan dunia mode dan fashion di indonesia selalu meningkat dari waktu ke waktu, Indonesia Fashion Week (IDFW) tahun 2018 mengungkapkan ekspor produk fashion indonesia setiap tahun terus meningkat." Tahun 2017 ekspor meningkat 8,7\% dan menyumbang kepada Produk Dosmetik Bruto (PDB) sebesar $3,76 \%$. Ini menunjukkan industri fashion indonesia memiliki daya saing di luar negeri, dibanding bidang lain, fashion cukup memberikan konstribusi besar pada ekonomi kreatif indonesia. Setelah di akuinya lagi Persebaya di persepakbolaan indonesia dengan bantuan dari supporternya yang loyal tersebut, persebaya yang sekarang kembali dengan manajemen baru yang sudah tersusun dan tertata dengan baik, sehingga membuat supporter muncul dengan image yang lebih baik dengan tidak rasis dan anarkis.

Dengan di akuinya lagi Persebaya yang sebelumnya vakum bertahun-tahun, dan rindunya supporter akan Persebaya membuat antusias yang tinggi dari supporter dengan cara selalu mendukung di laga home maupun away. Melihat antusiasnya supporter, manajemen persebaya berinisiatif membuka Store sendiri. (Yudha dalam situs www.kabarsurabaya.org). Salah satu team sepakbola di Indonesia yang memiliki merek resmi sendiri adalah persebaya yaitu Persebaya Store. dengan adanya merek, muncul rasa minat beli sebuah konsumen, Persebaya Store membuka gerai pertamanya sebagai merchandise resmi persebaya pada 16 maret 2017 di Lobby Graha Pena- Jl. A. Yani 88 Surabaya dan sekarang sudah pindah galeri di Surabaya Town Square, Jl, Hayam Wuruk No.06. Sejak diluncurkan sebagai pusat merchandise resmi persebaya.

Untuk permintaan konsumen dan semakin antusias pembelinya, Berdasarkan uraian latar belakang diatas maka penulis akan melakukan penelitian mengenai "Pengaruh Merek, Desain Produk Dan Lokasi Terhadap Minat Beli Konsumen Pada Persebaya Store Gresik".

\section{KAJIAN TEORI}

\section{Tinjauan Penelitian Sebelumnya}

Penelitian yang dilakukan oleh Adiba dengan judul "Pengaruh Suasana Toko Dan Lokasi Terhadap Minat Beli Konsumen Pada Aurora Shop Samarinda". Penelitian ini bertujuan untuk mengetahui variabel suasana toko dan lokasi terhadap minat beli konsumen toko Aurora Shop Samarinda, Penelitian yang dilakukan oleh Hotman, Makmur, Hidayat berjudul " pengaruh suasana toko dan lokasi terhadap minat beli ulang konsumen di UD. Naysila Toys Simpang SKPD. Penelitian ini 
bertujuan untuk mengetahui apakah suasana toko dan lokasi berpengaruh terhadap minat beli di toko UD. Naysila Toys Simpang SKPD. Penelitian yang dilakukan oleh Ni Putu Dessy Ari Apriliani dan I Gusti Ayu Ketut Giantara dengan judul " Pengaruh Suasana Toko Dan Lokasi Terhadap Niat beli Ulang Konsumen Di Minimarket Sekawan Tabanan", penelitian ini bertujuan untuk menguji dan menganalisis pengaruh (1) suasana toko terhadap niat beli ulang konsumen, (2) lokasi terhadap niat beli ulang konsumen di minimarket sekawan tabanan

\section{Merek}

Menurut Utami (2014: 250) Merek adalah suatu nama atau simbol pembeda, seperti misalnya logo, yang mengidentifikasi produk atau jasa yang ditawarkan oleh penjual dan membedakan produk atau jasa itu dari atau dengan penawaran pesaing. Dalam konteks bisnis ritel, merek dapat diartikan sebagai merek ritel itu sendiri ataupun merek produk atau barang dagang yang dijual atau ditawarkan oleh pihak ritel. Merek memegang peranan sangat penting salah satunya adalah menjembatani harapan pada saat kita menjanjikan sesuatu kepada konsumen.

Dengan demikian dapat diketahui adanya ikatan emosional yang tercipta antara konsumen dengan perusahaan penghasil produk melalui merek. Pesaing juga bisa menawarkan produk yang mirip tetapi mereka tidak mungkin menawarkan janji emosional yang sama. Keberadaan merek bermanfaat bagi pembeli, perantara, produsen, maupun publik. Simamora (2002) dalam Wicaksono (2015:17) bagi pembeli merek bermanfaat untuk menceritakan mutu dan membantu memberi perhatian terhadap produk-produk yang baru akan mungkin bermanfaat bagi mereka. Mereka mempunyai peranan yang penting dan merupakan aset yang menguntungkan bagi perusahaan. Dalam kondisi pasar yang kompetitif, preferensi dan loyalitas pelanggan adalah kunci kesuksesan

\section{Desain Produk}

Wicaksono (2015:18) desain merupakan totalitas keistimewaan yang mempengaruhi penampilan dan fungsi suatu produk dari segi kebutuhan pelanggan. Desain produk berfungsi untuk membedakan satu produk dengan produk lain. Menurut Rosnani
(2010:233) berpendapat bahwa desain dapat diartikan sebagai salah satu aktivitas luas dari inovasi desain dan teknologi yang digagaskan, dibuat, dipertukarkan (melalui transaksi jual beli) dan fungsional. Desain produk juga berhubungan dengan model yang beraneka ragam bentuk dan ukuran yang menarik. Jika model secara sederhana menjelaskan bentuk luar produk, sedangkan desain lebih dari sekedar kulit ari tetapi desain menjadi jantungnya produk yang mempertimbangkan bentuk luar, menciptakan bentuk produk mudah aman, tidak mahal untuk diproduksi serta ekonomi untuk didistribusikan.

Dari pengertian desain produk diatas dapat diambil suatu kesimpulan bahwa suatu perusahaan haruslah dapat menciptakan suatu desain yang menarik dan berbeda dengan produk pesaing yang sejenis. Semakin bagus desain produk akan sangat mudah diterima konsumen dan desain tersebut akan menjadi ciri khas akan produk yang diproduksi.

\section{Lokasi}

Menurut Utami (2017:175) lokasi ritel adalah sebuah keputusan yang sangat strategis. Sekali lokasi dipilih, pemilik ritel harus menanggung semua konsekuensi dari pilihan tersebut. Sebagai contoh sebuah ritel makanan mempertimbangkan lokasi toko di area yang masih baru. Pemilik ritel memilih dua tempat, bersebrangan dengan toko lain atau menempati lokasi yang benar-benar baru dengan tanpa pesaing toko makanan lain. Dalam membuat keputusan mengenai pemilihan lokasi, seharusnya pemilik ritel memikirkan dalam tiga tingakt, yaitu daerah, area perdangangan, dan tempat yang lebih spesifik.

Untuk memilih perdagangan tersebut, dapat digunakan beragam data untuk menganalisis lokasi-lokasi potensial. Terdapat berbagai metode dan data yang dapat digunakan dalam menganalisis lokasi-lokasi potensial bagi bisnis ritel, antara lain indeks perkembangan merek, indeks populasi, kluster prima, dan analisis toko pembanding. Evalusi mengenai kepadatan penduduk, tingkat pendapatan rumah tangga, tingkat pendidikan, ukuran rumah tangga dengan anak, ketertarikan daya hidup, semua informasi tersebut dapat digunakan untuk menentukan apakah lokasi perdagangan tersebut sesuai dengan yang diharapkan. Seleksi lokasi ritel adalah keputusan keputusan yang sangat strategis. Begitu lokasi sudah dipilih, 
sebuah ritel harus hidup dengan pilihan tersebut dalam jangka waktu yang lama.

\section{Hubungan Antar Variabel}

Hubungan Merek dengan Minat Beli

Wicaksono (2015:16) merek bertujuan untuk menghindari adanya pemalsuan produk tertentu, karena bila tidak disertai merek maka setiap pesaing mudah dalam meniru sebuah produk, tapi dengan adanya merek konsumen akan mudah dalam melakukan sebuah pembelanjaan atau pembelian dalam suatu produk

Hubungan Desain Produk dengan Minat Beli

Wicaksono (2015:20) bahwa suatu perusahaan haruslah dapat menciptakan suatu desain yang menarik, sehingga dengan menariknya desain tersebut akan mendapat nilai yang positif dari konsumen, agar muncul sebuah pembelian produk tersebut.

Hubungan Lokasi dengan Minat Beli

Raharjo (2017:19) lokasi sebagai sarana aktivitas perusahaan agarproduk mudah didapatkan oleh konsumen sasarannya. Lokasi yang strategis membuat konsumen lebih mudah dalam menjangkau dan juga keamanan yang terjamin. Sehingga dengan demikian, ada hubungan antara lokasi yang strategis dengan daya tarik konsumen untuk melakukan pembelian suatu produk.

\section{Hipotesis}

Merek, Desain Produk dan Lokasi secara simultan berpengaruh signifikan terhadap Minat beli konsumen pada Persebaya Store Gresik.

1. Merek Lokasi secara parsial berpengaruh signifikan terhadap Minat beli konsumen pada Persebaya Store Gresik.

2. Desain Produk Lokasi secara parsial berpengaruh signifikan terhadap Minat beli konsumen pada Persebaya Store Gresik.

3. Lokasi secara parsial berpengaruh signifikan terhadap Minat beli konsumen pada Persebaya Store Gresik.

\section{METODE PENELITIAN}

Pendekatan kuantitatif adalah penelitian yang menekankan pada penguji yang berhubungan dengan angka-angka, karena penelitian ini disajikan dengan angka-angka. Penelitian kuantitatif adalah pendekatan penelitian yang banyak dituntut menguakan angka, mulai dari pengumpulan data, penafsiran terhadap data tersebut, serta penampilan hasilnya untuk mengetahui hasil dari pengaruh
Merek, Desain Produk dan lokasi Terhadap Minat Beli Konsumen, Sugiyono (2010:7). Populasi yang dimaksud penelitian ini adalah pengunjung persebaya Store Gresik yaitu umur antara 16 samapai 35 tahun. besarnya sampel pada penelitian ini adalah 100 responden dan memenuhi syarat dan untuk menghitung penentuan jumlah sampel dengan menggunakan rumus slovin.

Pada penelitian ini, jenis data yang dipakai oleh peneliti adalah Data Primer yaitu kuesioner sebagai insrumen penelitian, guna menghasilkan data kuantitatif, skala likert sebagai skala pengukuran. Adapun teknik analisis data yang digunakan dalam penelitian ini adalah uji validitas, uji reliabilitas, uji asumsi klasik, persamaan regresi linier berganda, koefesien determinasi uji t dan uji $f$

\section{HASIL DAN PEMBAHASAN}

\section{Sejarah Singkat Persebaya Store Gresik}

Persebaya Store merupakan unit ritel baru milik persebaya surabaya yang didirikan untuk menjadi support dalam membangun image baru tentang klub Persebaya. Sebagai pusat penjualan merchandise resmi Persebaya (official merchandise store), yang berarti setiap pembelian merchandise di Persebaya store, secara langsung juga turut mensupport dan berkonstribusi untuk klub Persebaya Surabaya. Persebaya Store merupakan gerai pertama sebagai merchandise resmi persebaya yang di buka pada tanggal 16 maret 2017 di Lobby Graha Pena- Jl. A. Yani 88 Surabaya dan sekarang sudah pindah galeri di Surabaya Town Square, Jl, Hayam Wuruk No.06. Sejak diluncurkan sebagai pusat merchandise resmi persebaya.

Untuk permintaan konsumen dan semakin antusias pembelinya, Persebaya Store juga membuka cabang di kota-kota lainnya terutama di kota Gresik, Persebaya store Gresik berdiri dari bulan Oktober 2017 yang berlokasikan di Sukorame, Jl.Raden Ajeng Kartini No.286-Gresik 61111. Kota Gresik menjadi cabang pertamanya karena kota perbatasan Surabaya, yang menurut manajemen merupakan salah satu kota yang dekat dengan stadion Persebaya dan Gresik juga masih berbasis suporter Persebaya

Sampel Pengunjung Persebaya Store Gresik. Responden yang di tentukan sebagai sampel adalah sebanyak 100 pengunjung. 
Setiap responden diberi lembar kuisioner untuk memberikan jawaban atas pernyataan yang telah disediakan. Dalam penelitian ini, peneliti akan mengidentifikasi responden berdasarkan 2 karakteristik, yaitu jenis kelamin dan usia responden.

\section{Analisis Data}

Langkah - langkah menganalisis data dalam penelitian ini adalah sebagai berikut :

Langkah-langkah menganalisa data dalam penelitian ini adalah sebagai berikut :

1. Melakukan perhitungan untuk setiap variabel yang nantinya akan di analisis lebih lanjut dalam program SPSS, seperti tertera pada lampiran penelitian ini.

2. Melakukan analisis deskriptif variabel penelitian.

3. Melakukan pengujian asumsi klasik yang terdiri dari uji normalitas, uji multikolineritas, uji autokorelasi dan uji hesteroskedastisitas.

4. Melakukan analisis regresi linier berganda.

5. Melakukan pengujian koefisien determinasi $\mathrm{R}^{2}$.

6. Melakukan pengujian hipotesis kelayakan model ( uji F).

7. Melakukan pengujian hipotesis secara parsial ( uji T).

\section{Pengaruh Merek Terhadap Minat Beli}

Hasil pengujian hipotesis pertama menunjukkan nilai untuk variable Merek sebesar $0,000<0,05$, yang berarti bahwa Merek berpengaruh secara signifikan terhadap variabel Minat Beli Persebaya Store Gresik. Hasil yang signifikan menunjukkan peningkatan atau penurunan Minat Beli dipengaruhi oleh Merek. Dengan adanya merek yang resmi dan mudahnya menguasai pasar sehingga membuat konsumen merasa puas dengan merek yang berkualitas sehingga konsumen berminat untuk membeli produk tersebut.

Hasil yang signifikan ini menunjukkan bahwa Merek mampu menjadi faktor yang menentukan Minat Beli. Hasil penelitian ini sesuai dengan penelitian yang dilakukan oleh Wicaksono (2015) yang mengatakan bahwa Merek berpengaruh signifikan terhadap Minat Beli. Artinya semakin baik Merek dan menguasai pasar maka akan meningkatkan minat beli konsumen.

Pengaruh Desain Produk Terhadap Minat Beli
Hasil pengujian hipotesis kedua menunjukkan nilai signifikansi untuk variabel Desain Produk sebesar 0,672 > 0,05. Maka variabel Desain Produk (X2) terbukti tidak berpengaruh terhadap Minat Beli Persebaya Store Gresik. Hasil yang menunjukkan bahwa Desain Produk tidak pengaruh terhadap Minat Beli. Kurangnya desain yang menarik dan memperkenalkan ciri khas akan Persebaya di bandingkan pesaing sejenis sehingga masih kurang diterima oleh konsumen. Rosnani (2010:233) mengemukakan bahwa suatu perusahaan haruslah dapat menciptakan suatu desain yang menarik dan bebeda dengan produk pesaing sejenis. Semakin bagus desain produk akan sangat mudah diterima konsumen.

Hasil yang tidak berpengaruh ini menunjukkan bahwa Desain Produk tidak mampu menjadi faktor yang menentukan Minat Beli. Hasil penelitian ini bertentangan dengan penelitian yang dilakukan oleh Wicaksono (2015) yang mengatakan bahwa Desain Produk berpengaruh positif signifikan dan dominan terhadap Minat Beli. Objek penelitian yang digunakan oleh peneliti sebelumnya adalah kendaraan bermotor, dimana secara kasat mata perbedaan desain antara kendaraan bermotor satu dengan yang lainnya terlihat dengan jelas, sehingga berpengaruh terhadap minat beli. Sedangkan objek penelitian yang digunakan peneliti saat ini adalah produk baju yang secara kasat mata hampir sama dengan baju lain yang dijual di toko retail lainnya. hal ini dikarenakan keunikan desain yang digunakan oleh Persebaya Store adalah terdapat pada jenis kain yang digunakan. Sehingga dapat disimpulkan bahwa desain produk dapat mempengaruhi minat beli bergantung dengan bentuk dan tampilan dari luarnya..

Desain produk tidak menjadi faktor yang menentukan Minat Beli dikarenakan secara kasat mata produk yang dihasilkan oleh Persebaya Store sama seperti yang dijual di toko retail lainnya. Dikarenakan desain yang digunakan oleh Persebaya adalah terdapat pada jenis kain yang digunakan.

\section{Pengaruh Lokasi Terhadap Minat Beli}

Hasil pengujian hipotesis ketiga menunjukkan nilai signifikansi untuk variabel Lokasi sebesar $0,03<0,05$. Maka variabel Lokasi terbukti berpengaruh signifikan terhadap Minat Beli Persebaya Store Gresik. Hasil yang signifikan menunjukkan meskipun Persebaya Store buka di luar kota Surabaya tetap saja 
masih banyak konsumen yang berminat untuk membeli, karena dengan di bukanya ritel baru di Gresik sehingga semakin dekat dengan konsumen dan lebih mudah dalam menjangkau sebuah produk. Raharjo (2017;19)" menjelaskan lokasi sebagai sarana aktivitas perusahaan agar produk mudah didapatkan oleh konsumen sasarannya.

Lokasi strategis membuat konsumen lebih mudah dalam menjangkau dan juga keamanan yang terjamin.

Hasil yang signifikan ini menunjukkan bahwa faktor Lokasi mampu menjadi faktor yang menentukan Minat Beli. Hasil ini penelitian ini sesuai dengan penelitian yang dilakukan oleh adiba (2015) yang mengatakan bahwa berpengaruh signifikan terhadap minat beli. Keuntungan pemilihan lokasi yaitu mempunyai konsumen yang berkomitmen dalam jangka panjang dan akan menambah pertumbuhan bisnis ritel di jangka panjang.

\section{KESIMPULAN DAN SARAN}

\section{Kesimpulan}

Berdasarkan hasil analisis data dan interpretasi hasil maka kesimpulan yang diambil dari peneliti dengan judul "Pengaruh Merek, Desain Produk, dan Lokasi terhadap Minat Beli Persebaya Store Gresik" adalah sebagai berikut

1. Merek berpengaruh secara parsial terhadap Minat Beli Persebaya Store Gresik.

2. Desain Produk tidak berpengaruh secara parsial terhadap Minat Beli Persebaya Store Gresik.

3. Lokasi berpengaruh secara parsial terhadap Minat Beli Persebaya Store Gresik.

4. Merek, Desain Produk, dan Minat Beli berpengaruh signifikan secara simultan terhadap Minat Beli Persebaya Store Gresik.

\section{SARAN}

Berdasarkan hasil analisis, pembahasan, dan kesimpulan peneliti, maka rekomendasi dari peneliti dapat diberikan sebagai berikut :

1. Bagi Kantor Pusat Persebaya Store.

Ritel harus terus meningkatkan kreatifitas dan inovasi dalam memproduksi produkproduknya sehingga bisa diterima oleh konsumen dan menambah model yang bervarian sehingga memberikan rasa puas ketika membeli produk tersebut. Persebaya Store Gresik harus selalu berupaya menggali masukan konsumen terkait peningatan produk, seperti dalam hal penambahan ciri khas merek selain tulisan Official Merchandise dan Sertifikat keaslian. Persebaya Store diharapkan dapat memilih lokasi yang sangat strategis dan dekat dengan keramaian apabila berencana untuk membuka Store baru.

2. Bagi Peneliti Selanjutnya

Bagi peneliti selanjutnya hasil penelitian ini dapat digunakan sebagai referensi dengan memperbanyak jumlah-jumlah variabelnya dan menggunakan teknik analisis yang berbeda.

\section{DAFTAR PUSTAKA}

D. Durianto, dan Liana. C, (2004). Analisi efektivitas iklan televisi softener soft \& fresh di Jakarta dan sekitarnya dengan menggunakan consumen decision model, Jurnal Ekonomi Perusahaan,Vol.11 (no.1): 35-55

Darmawan, D, 2013, 2014. Metode penelitian kusntitstif, Edisi pertama Metode penelitian kuantitati, Edisi Kedua. PT. Remaja Rosdakarya Bandung.

Diakses dari situs www.persebayastore.com (di akses pada tanggal 17 april 2018).

Priansa, Juni, Donni, 2017. Perilaku Konsumen "dalam persaingan bisnis kontemporer" . Penerbit CV.Alfabeta, Bandung.

Ferdinand, Augusty, 2011. Pengembangan Minat Beli Merek Ekstensi. Badan Penerbit Universitas Diponegoro, Semarang

Gumilang, Marta Gerry, 2013, Pengaruh Emotional Value Terhadap Loyalitas Pelanggan Pada Kafe Warung Lela (WALE), Skripsi hal.28-36.

www.kabarsurabaya.id, Bonek untuk Surabaya yang lebih baik.

www.indonesiafashionweek.id indonesia fashion week 2018 mampu gairahkan perekonomian indonesia.

Kotler, Philip dan Keller, L. Kevin. 2003 Strategic Brand Manajemen, Second Edition, Prentice Hall

Lucas,D. Blaine \&Steuart H. Britt,2000. Advertising Psychology and Research New York:McGraw-Hill Book Company

Ni'mah, Maulidiatun, 2017, Pengaruh Kualitas Pelayanan, Harga, Lokasi, dan Store At 
mosphere Terhadap Keputusan Pembelian Konsumen di Tool Station Gresik, Skripsi Manajemen, Universitas Muhammadiyah Gresik.

Pardede, Ratlan, 2014. Analisis Jalur, Edisi Pertama. Penerbit Rineka Cipta.

Raharjo, Yoga, 2017. Pengaruh Suasana Toko dan Lokasi terhadap Minat beli Konsumen di matahari departemen store Gresik, Skripsi Universitas Wijaya Kusuma, hal 17,24.

Schiffman, Leon.G. dan Kanuk, Leslie. (2004). Consumer Behavior. Prentice Hall InternasionalInc, Bandung

Shella, Fattah, Enny, 2017, Pengaruh Nilai Emosional, Nilai Pengorbanan, dan Loyalitas Merek Terhadap Kepuasan Konsumen MC'DONALDS di Sidoarjo, Manajemen Universitas Bhayangkara Surabaya, Jurnal Ekonomi hal. 154-155.

Sugiyono, 2010. Metode Penelitian Kuantitatif, Kualitatif dan $R \& D$. Cetakan ke-11, penerbit Alfabeta, Bandung.

Tim Penulis, 2016. Pedoman Penulisan Proposal dan Skripsi, Edisi Revisi, Fakultas Ekonomi dan Bisnis, Universitas Muhammadiyah Gresik.

Tjiptono, Fandy. 2006. Manajemen Jasa. Edisi Pertama. Yogyakarta : Andi.

Utami,Widya,C. 2014,2017. Manajemen Ritel Edisi Kedua, Manajemen Ritel Edisi Ketiga. Salemba Empat. Jakarta.

Wicaksono A. Satria, 2015, Pengaruh Merek dan Desain Terhadap Minat Beli Konsumen, Skripsi Prodi Manajemen Universitas Negeri Semarang, hal. 17-18. 